\title{
Cultural Studies for Oceania
}

Houston Wood

\begin{abstract}
A
cross Oceania's deep sea of knowledges, amid multiple unresolved social and political tensions, I sense a new perspective emerging among researchers whose training spans many disciplines. This perspective seems built on a common belief that continental disciplines are incapable of serving the needs of the majority of people in Oceania. Native and non-Native researchers, credentialed in fields as divergent as geography is from English, as anthropology is from geology, are collaborating to create a new research practice unlike any previously seen in Oceania or elsewhere.

This emerging perspective lacks an agreed-on name, but, borrowing from suggestions found in various sources, the label "cultural studies for Oceania" seems apt. ${ }^{1}$ Cultural studies, after all, as Stuart Hall explained, insists on the importance of specific locations in creating "contested localized knowledges" (I992, 292). Oceania's rich, dynamic "sea of knowledges" seems especially suited for such a perspective. ${ }^{2}$ The region is stunningly fluid, multiple, and complex, as Teresia Teaiwa has repeatedly stated (200Ia). Nonetheless, if cultural studies is to be in, of, and for Oceania and not merely another colonizing continental import, it will have to be adjusted to absorb, without resolving, multiple tensions currently bubbling within the region. One prominent example of such tension is associated with the manifold incompatibilities that exist between Euro-American and Native Pacific Islander epistemologies.

Konai Helu Thaman's poem, "Our Way" illumines this tension (I987, 40). Euro-American epistemology, called "your way" in Thaman's verse, is generally the way of "objective analytic / always doubting the truth / until proof comes slowly." By contrast, for Thaman, "my way," the Pacific Islander way, is more "gut-feeling like / always sure of the truth / the proof is there waiting." A cultural studies for Oceania will have to integrate each
\end{abstract}

The Contemporary Pacific, Volume I5, Number 2, Fall 2003, 340-374

(C) 2003 by University of Hawai'i Press 
of these ways of knowing, as well as many others. These multiple epistemologies must be embraced in a cultural studies for Oceania not despite of the fact that each produces different truths and realities, but precisely because such multiplicities are and should remain a valued manifestation of this fluid and complex region.

It is especially important that the emerging cultural studies for Oceania prominently emphasize Pacific Islander ways of knowing. After centuries of colonialist-inspired neglect, indigenous researchers have begun documenting the complexity, subtlety, and validity of indigenous epistemologies. ${ }^{3}$ As David Welchman Gegeo has remarked, this documenting work is creating an "epistemic transformation" in the region (200Ia, I8I). However great their strength, there seems to be agreement that traditional Oceanic ways of knowing are no longer sufficient in themselves, though they were sufficient in Oceania in the past. Currently many islands, sea-lanes, and material resources in the region are controlled largely by people (both settlers and Pacific Islanders) who reject out-of-hand projects or ideas based primarily on traditional epistemologies. Arguments that employ Euro-American rhetorics have at least some small chance of suasion in discussions with this dominant elite. Thus for many years it will probably continue to be necessary to translate some conclusions from Pacific Islander perspectives into the foreign, rationalist discourses introduced into the region by Euro-Americans. Making these translations on behalf of Pacific Islanders seems likely to be one important task for the emerging cultural studies of Oceania. 4

However, translating Islander perspectives into Euro-American discourses is risky because many in the region, as elsewhere, embrace the imperialist conceit that Euro-American epistemologies generate universally valid knowledge. The risk is that those who believe in this notion will accept "translations" of Oceanic cultural knowledge as re-presentations that make the Other available to anyone able to study written and visual texts. Such readers will tend to treat translations of Pacific knowledges into Euro-American discourses as reaffirmations that western epistemologies are able to re-present Pacific Islanders traditions without fundamental losses in truth or accuracy.

Practitioners of the emerging cultural studies of Oceania are seeking ways of referring to Pacific Islander realities using Euro-American discourses while simultaneously undermining colonialist assumptions about the supposed universal applicability of those discourses. In this article I describe multiple research practices that attempt this difficult task. This 
emerging decolonizing project is rendered especially difficult because invocations of notions such as freedom, equality, sovereignty, the rule of law, and human rights, though grounded in Euro-American discourses, nonetheless often provide opportunities for opposing colonization. Dipesh Chakrabarty has argued that the majority of terms used in decolonizing projects are "impossible to think of anywhere in the world, without invoking certain categories and concepts, the genealogies of which go deep into the intellectual and even theological traditions of Europe" (2000, 4). By strategically adapting some concepts from the dominant discourse of continental elites, a cultural studies for Oceania will be effective when it insists that the people of the region should be allowed at least as much national freedom and economic and cultural sovereignty as North Americans and European elites allow themselves. Invoking these or any EuroAmerican concepts, however, may simultaneously strengthen the faith of those who believe that imported discourses are generally superior to indigenous Pacific ones.

One goal of the various practices discussed in this article is to form a region-specific cultural studies practice built from both Euro-American and Oceanic traditions, while overcoming the current hegemony of the former. The general goal for Pacific Islanders involved in this project thus seems to be much like that explained by Missy, a Māori character in Patricia Grace's novel Cousins (1998). "It's not sticking to the old ways that's important," Missy declares in summarizing what her cousin Makareta taught her. "It's being us, using all the new knowledge our way. Everything new belongs to us too" (Grace 1998, 235). Practitioners of the emerging cultural studies for Oceania are adapting "the new knowledge" from the West to use for their own purposes, to use in "our way," as both Thaman and Grace have phrased it.

The activities of non-Native practitioners associated with the emerging cultural studies are necessarily different from the activities of many Native researchers. ${ }^{5}$ No outsider or settler researchers should be permitted free access and rights of adaptation of Native cultures like those that Pacific Islanders assume when encountering continental ways. Non-Natives, for example, should no longer be allowed to claim for their disciplines, organizations, or corporations whatever resources they wish to take from the immense sea of Native knowledges scattered across Oceania. Such restrictions in access are necessitated by the contemporary asymmetries of power present throughout the region. "Being us, using all the new knowledge our way," as Grace described it (1998, 235), little threatens the autonomy of Euro-American cultures. In fact, as Chakrabarty has pointed out, such 
uses of "European thought" by non-Euro-American cultures are likely to enrich western traditions (2000, I6). The reverse is not true, however, because widespread Euro-American adaptations of aspects of Pacific Islander cultures further accelerate fundamental changes in how those Native cultural practices are perceived and enacted at their source. Access to and adaptations by non-Native researchers must be controlled by Natives, then, as must access that is permitted to other non-Natives as well.

The issue of different levels of access to Oceania's sea of knowledges for Native and non-Native practitioners suggests that identity issues are central, while also potentially poisonous, to the emerging cultural studies for Oceania. In turning to an examination of several emerging research practices then, it seems best to begin with identity.

\section{INDIVIDUAL IDENTITY}

Most would agree with Jon Kamakawiwo'ole Osorio's claim that identity is "the foundation on which Native cultural studies is based" (200I, 36I). In reading publications and attending conferences, determining who is and who is not Native has become central. People want to know not only who is conducting each research project but also the identities of who is to be the subject of research, whom the research serves, and to whom findings will be reported (see Smith I999). As Geoffrey M White and Ty Kāwika Tengan pointed out, however, there is considerable irony in the continuing maintenance of a Native and non-Native binary. Though non-Natives first built the numerous political and institutional barriers that keep the two identities separate, the binary is now often "policed by the same Natives formerly bound as its object" (White and Tengan 200I, 395). Gegeo warned that such policing can be destructive: "We must be careful, because battles over degrees of ethnicity or cultural identity-whether one is more Native or Indigenous than someone else-are metropolitan battles that have been imported into Pacific cultures" (200I b, 502). Indigenous identities in the region have traditionally embraced much more fluidity than the imported Euro-American concepts of identity allow.

Ironic and dangerous though it may be, there remain many occasions when it seems best to distinguish between Pacific Islander and non-Pacific Islander identities. Earlier non-Pacific Islander researchers in the region did not often refer to their own identities in their accounts, as it was assumed all researchers would be white, male, non-Native, and nonIslander. The cultural and ethnic homogeneity of earlier researchers pre- 
cluded much need for policing the Native and non-Native boundary within research institutions; there were few non-Native researchers to police. When, on rare occasions, questions about the impact of identity on research were raised, non-Native researchers generally asserted that their "objective methods" neutralized any bias that might be associated with their Euro-American identities.

However, it is now evident that scientistic, continentally imported methods were never value neutral; in fact they systematically undermined the prestige and legitimacy of the many Native methods of knowing that preceded the entry of non-Natives into Oceania (Smith I999). Because many of these same continental methods are still being employed by Natives and non-Natives alike, people throughout Oceania now are asking: What is the identity of the researcher? What (if any) is the researcher's familial connection to the region? Why does the researcher, as a Native or as a nonNative, continue to employ Euro-American categories, theories, and methods to research Oceania's Native peoples?

Because it took the protests of Pacific Islanders to initiate substantial changes in the focus of research in Oceania, the issue of whether or not a researcher is a Pacific Islander will likely remain important within a cultural studies for Oceania for years to come. And although it is now generally valued to specify that one is Native (whether one is a researcher or not), this often raises almost as many questions about one's identity as it answers. To be Native in Oceania today suggests an identity that can include practices and attitudes drawn from many cultures, including Euro-American, Anglo, Asian, and even African. Earlier specifications of a Native identity in Oceania relied on oppositions, especially oppositions to practices imported from continents. But now such oppositions have, if not disappeared, receded remarkably. For example, contrary to suggestions in her earlier work that Pacific Islander identities be understood as opposing continental militarism and tourism (eg, Teaiwa I994; 1999), Teaiwa has recently maintained that identities of contemporary Natives in Oceania are better conceived of as being continually articulated, disarticulated, and rearticulated, not only with militarism and tourism, but also "with other institutions, ideologies, cultural forces, and presences such as femininity, masculinity, Christianity, 'race,' the state, and capitalism" (200Ia, 7). Natives in Oceania appropriate and transform these institutions, as they are appropriated and transformed by them. Teaiwa's recent argument asserts that analysis that treats continental social formations as separate, opposed to, or distinct from Native identities misconceives the situation of Pacific Islanders in the contemporary world. 
Based in part on James Clifford's 1997 elaboration of Paul Gilroy's earlier analyses (I99I, I993), the general view of Pacific Islander identities described by Teaiwa grounds the emerging cultural studies for Oceania. ${ }^{6}$ Vicente M Diaz and J Kēhaulani Kauanui have explained this view of Native identities as resulting from articulations of the traditional "rootedness" of Pacific Islanders with the global "routes" many traverse today (200I). In separate theorizing, not drawing explicitly on Clifford or Gilroy, Vilsoni Hereniko invoked similar articulations of root/route trajectories when he described "Islanders who live in urban centers and hold white-collar jobs [and] feel Pacific . . . yet speak English, wear Western clothing, and pay rent or mortgages. Torn between being traditional (which usually means behaving and holding the same values as their rural counterparts) and being realistic (adopting certain European or American manners, certain kinds of dress and values), they are often unable to reconcile these seemingly conflicting notions of identity" (I999, I 50). Many left their homelands early in their lives, or, increasingly, were born on islands or even continents far away. Because such Islanders seldom return to their ancestral islands except for visits, they have little direct experience of the physical places on which their identities are based. Many also have parents and grandparents of mixed heritages, each of whom contributed to their upbringing and each of whom might also provide them with a non-Islander identity. ${ }^{7}$

Even this does not exhaust the complications associated with Native identities. Some Islanders who are Native to one Pacific island or island group have now lived for generations as a coherent community on neighboring Pacific islands. Most still think of themselves as Natives of their earlier, ancestral place. ${ }^{8}$ Consider also the complex situation common to descendents of long-time non-Native settlers on one island or another (eg, the whites, Japanese, and Chinese in Hawai'i; Filipinos in Guam and Hawai'i; Indo-Fijians in Fiji; whites in New Zealand). By most accounts, one hundred years and more make these settler-descendents natives of but not Native to the islands of their great-great-grandparents' births. In addition, deep differences remain between the cultures of long-time settlers and recent immigrants.

Hereniko suggested one strategy for dealing with these complications, substituting a more Oceanic perspective on identity for a western view that treats identity as a static category (I999). The western perspective is typified by the bureaucratic forms and applications that ask people to choose one identity label from a limited range of possibilities. In many nations throughout Oceania, parents completing such forms inadvertently 
stamp their newborn children with a fixed ethnic identity for the rest of their lives. Hereniko has recommended a different understanding, one that recognizes identities as continually shifting, as repeatedly created through situationally specific negotiations across multiple group memberships: "Our cultural identities are therefore always in a state of becoming, a journey, in which we never arrive; who we are is not a rock that is passed on from generation to generation." Identity is a practice of ongoing articulations rather than a state, "process, not product" (Hereniko I999, I38). Such a view of identity formation parallels the shift in the emerging field of cultural studies of Oceania, from an emphasis on products to an emphasis on processes of production-an important shift I describe further in a later section.

Treating identity as an ongoing process of articulation will not end disputes about personal identities, because these claims have important material and symbolic consequences. Identities often determine, for example, who can vote, who can own land, who can receive aid, who is invited to speak. These consequences will continue to be negotiated throughout Oceania and beyond, with passion and occasional violence. But shifting to a more fluid notion of identity does immediately accomplish one important task, inasmuch as it encourages resistance to what Diaz and Kauanui referred to as the "reified identities" that have too often been used "to commodify or cheapen" Pacific Islanders; "the injection of mobility in how we conceptualize identity and culture can be liberating so long as the native is not lost altogether" (200I, 324).

Keeping the identities of Pacific Islanders from being lost through continual articulations, disarticulations, and rearticulations seems to depend on maintaining an articulation with what Epeli Hau'ofa referred to as a "homeland" (2000). This articulation provides assurance that "somewhere in Oceania is a piece of earth" to which each Native Pacific Islander belongs (Hau'ofa 2000, 470). It is this sense of a homeland that "adds a sense of continuity" to the various ongoing identity articulations Pacific Islanders enact (Clifford 2000, 98).

\section{REgIONAL IDENTITY}

Because each homeland is unique, individual articulations with multiple specific places in Oceania discourage the construction of a unifying regional identity. Still, as Teaiwa declared, "In Oceania, the need for regional cooperation is as urgently needed, as it is difficult to achieve" 
(200Ia, I 50). This difficult search for "unifying connections" is a central goal for people associated with the emerging cultural studies for Oceania (Gegeo 200Ia, I82).

People associated with established academic disciplines-such as anthropology, history, literary studies, sociology—generally seek to serve their disciplines first, and the people and regions they study only secondarily. ${ }^{9}$ Cultural studies in Oceania, on the other hand, exists first for Oceania and only secondarily, if at all, to further the theoretical or institutional goals of the international cultural studies movement. Helping to build a regional identity for the region, then, can be a first priority for a cultural studies for Oceania.

Building such an "explicitly regional or cross-cultural inter-islander" identity, as Teaiwa phrased it (2001a, 33), may be endorsed by but is not a high priority for the various Native Studies communities throughout Oceania. These communities include those associated with Chamorro Studies in Guam, Hawaiian Studies at the University of Hawai'i, Māori Studies in various locations in New Zealand, and Samoan Studies at universities in both Sāmoa and New Zealand. Because Native Studies focus on particular "nationalistic or sovereignty movements" (Teaiwa 200Ia, 69), they do not expend much effort in creating a unifying regional identity. It remains for a cultural studies in and for Oceania to make formulating and disseminating such an identity a central focus.

Obstacles abound. As Hau'ofa has noted (I993; I997), colonialism constructed material and ideological barriers that have disrupted traditional practices connecting Pacific Islanders across large and small distances. For example, colonialism encouraged the construction of "nations," which in turn expedited the practice of policing arbitrary borders on land and sea in ways that destroyed traditional trade routes. Similarly, the continentally inspired adoption of the divisive categories of Melanesia, Micronesia, and Polynesia has encouraged Pacific Islanders to conceive of themselves as separated by conceptual barriers based not on their own perceptions but on the ways they were perceived by outsiders (Gegeo 200Ib, 502). These and most other colonialist concepts describing Oceania have undermined customary ways of forging inter-island connections. One aim of the new cultural studies for Oceania is to assist in the discrediting and retiring of imported concepts that build barriers to cooperation across and beyond the region.

The yearning to create a regional identity to counter colonialism is not new. Bernard Narokobi argued for years to try to get people to embrace 
a regional identity he called "the Melanesian Way" (I980). Similarly, after Fiji Prime Minister Ratu Sir Kamisese Mara used a related phrase in addressing the UN General Assembly in 1970, notions of a trans-oceanic "Pacific Way" became common (Fortune, 2000). The concept of a unique regional "Way" was, for a while, widely accepted, especially by Englishlanguage elites, in part because such ideas were embraced both by AngloEuropean and American social scientists and by people-Natives, settlers, and foreigners-doing business across the region. For many, however, speaking of "the Melanesian or Pacific Way" was mostly an indirect means of asserting that Islanders are "lazy Natives" (compare Teaiwa I995b).

Apart from their negative connotations and association with elites, visions of "a Way" seem poor candidates to use in building a unifying regional identity for the twenty-first century. The Way approach depends in large measure on contrasts with an opposite term, a posited "western," "modern," or "Euro-American" Way. Surely, however, the region's identity is best grounded in concepts independent from a colonized/colonizer, or west/rest, binary. In addition, the Pacific or Melanesian Way approach works against valuing one of the most important features of the region, which is, as Albert Wendt has noted, that Oceania has "a cultural diversity more varied than any other in the world" $(1976,57)$. In a region with I,200 indigenous languages, plus several settler-imported tongues and numerous pidgins and creoles, more is likely lost than gained by positing some supposed common culture as grounds for building a regional identity.

In his seminal 1976 article, “Towards a New Oceania," Wendt's alternative vision for the region stresses connections among artists across the region more than connections among ordinary people. Wendt declared, "Our [artists'] ties transcend barriers of culture, race, petty nationalism, and politics ... In their individual journeys into the Void, these artists, through their work, are explaining us to ourselves and creating a new Oceania" (1976, 59, 60). Subramani's subsequent related essay, "The Oceanic Imaginary," similarly emphasizes the power of artists, and especially creative writers, to forge a unifying vision for the region (200I). In his establishment of the Oceania Centre for Arts and Culture at the University of the South Pacific (USP) in Suva, Fiji, Hau'ofa might be seen as allying himself with Wendt's and Subramani's faith in the transformative potential of art. Hau'ofa's project, however, is broader. He includes artists 
as but one among many communities in Oceania he hopes will embrace a common heritage in the sea.

In "A Sea of Islands" (I993), Hau'ofa inaugurated his project of building a regional identity by emphasizing that Pacific Islanders have a long history of connectedness, trade, exploration, and reciprocity, a history temporarily slowed but not ended by colonialism. In "The Ocean in Us," Hau'ofa went further to offer "a substantial regional identity that is anchored in our common inheritance ... the Pacific Ocean" (I997, I 24). The ocean "that surrounds and sustains" everyone in the region can become a unifying force across the immense sea of islands (I 25). Hau'ofa concluded that "the sea is our pathway to each other and to everyone else, the sea is our endless saga, the sea is our most powerful metaphor, the ocean is in us" (I48). Hau'ofa insisted that this or any regional identity should not diminish differences within the region. Diversity is essential in "the struggle against the homogenising forces of the global juggernaut" (I26). Hau'ofa's regional identity rooted in the ocean thus does not aim to replace but instead to add to the numerous, particular cultural identities people already possess. Both indigenous and nonindigenous people are invited to embrace an identity rooted in the ocean, Hau'ofa declared, for all who settle in the region share the sea "as our single common heritage" (I42). Establishing a regional identity is vital, Hau'ofa argued, because smaller groups and countries working alone have little chance of protecting themselves against global capitalist expansion. Together, working as a unified region, opposition to environmental degradation and transnational expansionism will more likely have some effect.

Hau'ofa's vision has provoked many responses (eg, Waddell, Naidu, and Hau'ofa I993; Kempf I999). Citing remarks by an unnamed representative from Papua New Guinea at a meeting in Suva in 1997, Margaret Jolly pointed to one problem with the vision: Many Pacific Islanders, perhaps the majority, "have no senses of ancestral connections to the ocean, no knowledge of how to make canoes, and indeed [have] never seen the sea" (200I, 423). Even on many smaller islands where the ocean was once central to society, both Pacific Islanders and settlers increasingly reside in environments that discourage intimacy with the sea. Nonetheless, despite these and other problems, Hau'ofa's insistence on the urgent need for a regional identity remains persuasive. It seems likely, though, that the sea can form but a part, and not the whole, of a vision that will bring the region closer together. 
Embracing a cultural studies that employs most if not all of the practices described in the rest of this essay may help people build a sense of belonging to a single region with related concerns.

\section{Process}

One way to root cultural studies in Oceania is to encourage researchers to shift their emphases from ends to means, from disciplinary productssuch as reports, articles, and books - to the mundane processes people participate in while doing cultural studies.

Lilikalā Kame'eleihiwa's Native Land and Foreign Desires: Pehea Lā E Pono Ai? provides a useful way to think about this shift from products to processes (1992). Kame'eleihiwa's book was the first extended history of Hawai'i to be published by a Hawaiian since the works of Samuel M Kamakau and David Malo appeared in the first half of the nineteenth century. ${ }^{10}$ Kame'eleihiwa marked her departure from the long tradition of foreigner and settler histories of the Islands by insisting that historical Hawaiians be understood through the lens of the internalized metaphors that guide Hawaiian experience and behavior. (The further importance of Islander metaphors in generating theories for cultural studies will be discussed later.) Kame'eleihiwa's emphasis on pono, one particularly dominant Hawaiian metaphor, illustrates how the emerging cultural studies for Oceania can change research centered on the region.

Kame'eleihiwa wrote, "The question that arises continually for Hawaiians is and has been 'Pehea là e pono ai?' that is, "How is it that we shall be pono?" (I992, 3II). To be pono, she explained, is to act appropriately to generate a "perfect equilibrium" in one's private and communal life (г3). Even when traders, settlers, and Calvinist missionaries in nineteenthcentury Hawai'i introduced "a new set of rules for the determination of pono" (I39), many Hawaiians still strained to maintain harmony in all aspects of living. Though the new missionary rules required divisions among political, economic, and religious spheres, according to Kame'eleihiwa, the Hawaiian sense of pono required that these practices remain intertwined. Much confusion ensued among Hawaiians at all levels of the social hierarchy in the nineteenth century as they tried to remain pono in a shifting context that, for example, was beginning to treat the land and ocean as spheres of economic but not of spiritual activities. Additional confusions arose over American-inspired efforts to create a division between "church and state," a separation of spiritual and political spheres 
Hawaiians experienced as joined. The deep puzzlement among Hawaiians about which acts were pono in the new context allowed foreigners to manipulate laws intended to empower Hawaiians so as to disempower them instead. ${ }^{11}$

The continental separation of spheres that Kame'eleihiwa described occurring in nineteenth-century Hawai'i has analogues throughout Oceania. The emerging cultural studies seeks to help put various now-separated spheres back together. Politics should no longer be left to the politicians and political science departments, nor spiritual concerns restricted to churches or to certain designated times of the day and week. Questions about what Hawaiians call pono, about how to harmonize all aspects of life, should be foremost, for both Native and non-Native researchers. The emerging stress on process encourages researchers to consider that every act is a constituent of a broader enactment of culturally appropriate knowledge. Knowledge so conceived can no longer be extracted from informants and research "instruments" to be translated into representations residing in museums, equations, films, or books. Oceania's culturally appropriate knowledge requires its own vibrant cultural contexts and processes.

What matters most in the emerging cultural studies, then, is not what researchers report but how they conduct their lives. Just as Kame'eleihiwa described many nineteenth-century Hawaiians being confused about how to act properly in their rapidly shifting cultural context, so too do both Native and non-Native researchers today struggle to decide which acts are appropriate in their own era of rapid change. Acknowledging that proper and improper actions exist is a first step. Though making unequivocal decisions may not always be possible, in a cultural studies for and of Oceania the existence of these complexities no longer justifies using continental approaches to research that privilege research results over research processes. ${ }^{12}$

\section{RECIPROCITY}

Partly because of their emphasis on identities and on processes, researchers in the emerging cultural studies for Oceania increasingly perceive themselves as members of the communities they study. Researchers thus embrace the intricate webs of reciprocal obligations that such active community membership requires. Even though, as Hau'ofa has pointed out, such interdependent networks of reciprocity have long been at "the core 
of all Oceanic cultures" (I993, I 2), 13 most earlier researchers in Oceania avoided becoming members of the communities they studied. They worked in while not being of Oceania and its routes of reciprocal exchanges. By holding themselves apart and disparaging those occasional few who "went native," researchers claimed to be avoiding "bias" and to be building "objective knowledge." People who possessed knowledge but not distance were designated "clients," "respondents," and "informants." Those who learned from these clients, respondents, and informants without accepting the community's customary reciprocal obligations called themselves "experts." Experts generally circulated their knowledge among themselves, more outside than inside Oceania. Nonetheless, these outsider experts often managed to shape military, political, and economic decisions that had significant material consequences for the peoples of Oceania.

As White and Tengan have noted, in the last few decades the increase in the number of "indigenous researchers working in home societies" has helped precipitate a fundamental reassessment of the value of anthropological fieldwork and of other research strategies (200I, 394). This influx of Native researchers responds to Wendt's earlier plea, where he mocked those who would reduce the region to "mundane fact[s]" and declared: "A detached/objective analysis I will leave to the sociologist and all the other 'ologists who have plagued Oceania . . Objectivity is for such uncommitted gods. My commitment won't allow me to confine myself to so narrow a vision" (I976, 49). Wendt called for indigenous people, as quickly as possible, to take the places of the outsiders who act as experts in and on the region.

Decades later, Wendt's vision is on the way to fulfillment. In Decolonizing Methodologies, Linda Tuhiwai Smith described multiple tactics researchers are using to maintain reciprocal community obligations within their work (I999). She focused on what she called "decolonizing research" undertaken by Māori in Aotearoa, insisting that "researchers have to share their 'control' of research and seek to maximize the participation and the interest of Maori" (I999, I90). A pioneering example of a researcher's commitment to reciprocity can be seen in John Dademo Waiko's attempts to share with his family, clan, and village the knowledge about them represented in his PhD dissertation (Waiko I982). The documentary film Man Without Pigs explores Waiko's efforts (Owen 1990). Some more recent examples of researchers working to keep research findings within their communities are the book-length histories of Kānaka Maoli by Kame'eleihiwa (1992), Osorio (2002), and Noenoe K Silva 
(IP b); Gegeo's studies of contemporary Kwara'ae epistemologies (I994; I998; with Watson-Gegeo 200I); Hereniko's monograph on clowning in Rotuma (1995); and Thaman's several articles on the place of Oceanic perspectives in Pacific Islander education (eg, 2000; 2003). Though many of these researchers do not reside full-time in what Hau'ofa called their "homelands" (2000, 470), none base their expertise on being an "objective" outsider; none renounce the web of reciprocal obligations their homelands membership entails.

The acceptance of reciprocal obligations is beginning to appear in the work of non-Native researchers in the region as well. For example, in $A$ Straight Path: A Story of Healing and Transformation in Fiji, Richard Katz concluded that "we [outsiders] must insist that the one-way coercive process of research change into a two-way process that is entered into freely. We can then commit ourselves to devoting as much energy to giving as historically has been devoted to taking-and more" (1993, 367; quoted in Hereniko 2000a, 90). Reshela DuPuis' I997 dissertation, "Documenting Community: Activist Videography in Hawai' $i$," is an extended example of how non-Native researchers can shape their work to make it serve those they study more than the academic disciplines they have traditionally assumed to be their primary community. DuPuis focused on dozens of videos created in Hawai'i by a group of mostly female videographers in the final decades of the twentieth century. Though her thesis committee urged DuPuis to view this community through the lens of Euro-American feminist theory, DuPuis instead encouraged the videographers to use her presence among them as an occasion to develop with each other their own analyses of their common history. DuPuis interviewed videographers and their documentary video subjects. She later submitted her notes and analysis to the interviewees, invited their comments, revised on the basis of what they said, resubmitted her revisions to them, and so on. DuPuis explained that "comments, corrections, contestations, addendums, differences of opinion and further stories were then incorporated into the text and footnotes in later drafts" (I997, I4). The resulting study provides this community with a document reflecting its history, shaped more by the memories and interpretations of the participants than by the theories of history (particularly of women's history) fashionable among continental academics at the time DuPuis wrote. ${ }^{14}$

The research challenges facing non-Natives such as Katz and DuPuis differ from those confronting Native researchers. ${ }^{15}$ Still, both non-Native and Native researchers experience similar enticements to identify more 
with the dominant communities associated with conventional academic research practices than with the less powerful communities that researchers (usually) study. Dominant communities, after all, generally provide more money, prestige, and swagger. However, a hundred years of westerninspired research in the region has made it evident that fulfilling the obligations associated with membership in these dominant communities generally decreases a researcher's participation in Oceania's networks of reciprocity. Workers in the emerging cultural studies for Oceania need to support each other in their various efforts to keep local communities at the center of every stage of their research processes.

\section{EPISTEMOLOGIES}

As these discussions of identity, process, and reciprocity suggest, the emerging cultural studies for Oceania rejects claims that western science and disciplines possess epistemologies superior to the local epistemologies found throughout Oceania. As Gegeo remarked, "What good is political independence if we remain colonized epistemologically?" (2001a, I 82). Just as I argue later that it requires multiple theories, so, too, does the emerging cultural studies for Oceania demand multiple epistemologies.

Manulani Aluli Meyer has noted that epistemological concerns include questions such as "What is knowledge, How do we know, What is worth knowing?" (200I, I46nI). Pacific Islands research based on Euro-American answers to these questions generally helps perpetuate Euro-American dominance in the region, even when the goals of this work are supposed to be anti-hegemonic. What Smith declared for herself and for other Māori is true as well for many other Native peoples in Oceania: "We have a different epistemological tradition which frames the way we see the world, the way we organize ourselves in it, the questions we ask and the solutions which we seek" (I999, I 87-188).

Anne Salmond pioneered academic, Oceanic-grounded critiques of western epistemologies (1985). Salmond interrogated the continental claim that the Māori create knowledge in a "closed" system that is less open to empirical verification and change than is the epistemology used by AngloEuropean researchers. Salmond demonstrated that such claims of Māori "irrationality" are based more on ideology than fact. Simultaneous with and subsequent to Salmond's work, refutations of the universalistic claims of Anglo-European positivism have become common, even on continents. However, it has proven much easier for researchers to critique the weak- 
nesses inherent in western empiricism than to elaborate and practice Native-inflected research alternatives. But despite the difficulties, elaborating and practicing nonwestern ways of knowing is a central goal of the emerging cultural studies for Oceania.

Salmond sketched some of the ways that Māori produce maatauranga, which she translates as "reliable knowledge" (I985, 240). Earlier, Mary Kawena Pukui shared with her coauthors of the two volumes of Nāna $i$ ke Kumu (Look to the Source) related insights into Native Hawaiian epistemology (Pukui, Haertig, and Lee 1972; 1979). Rob Borofsky similarly focused on the validity of Native ways of knowing in his Making History: Pukapukan and Anthropological Constructions of Knowledge (1987). More recently, Gegeo and Karen Ann Watson-Gegeo (eg, 200I, 2002), Meyer (I998; 200I), and Smith (I999) have published impressive epistemological studies of the Kwara'ae (Solomon Islanders), Hawaiians, and Māori, respectively. These more recent studies move beyond using Native epistemologies mostly as tools with which to critique colonial and settler imports, though they do some of that. Each focuses primarily, instead, on articulating the discourses that already exist among Natives for theorizing both about what constitutes valid knowledge and about how worthwhile knowledge is best constructed. Describing the sophistication of existing Native epistemologies is valuable not only to refute continuing AngloEuropean claims that the people of Oceania are premodern, primitive thinkers, but also to make more available to researchers Native epistemologies that they can use in their research as alternatives to the continental epistemologies still emphasized in most Oceanic schools.

Studies of Native Oceanic epistemologies completed so far suggest that there may be several common features. For example, the recent separate studies by Gegeo and Watson-Gegeo, Meyer, and Salmond each suggest that often in Oceania (I) valid knowledge requires culturally prescribed dialogue with others; (2) some participants in these required dialogues may be spirits or otherwise not physically present; (3) valid knowledge is associated with bodily sensations; (4) valid knowledge is in part determined by its utterance in prescribed forms in specific places; and (5) the validity of knowledge does not depend on its also being valid in communities beyond the specific place of its making. Each of these features suggests a markedly different view of valid knowledge than that associated with most current research paradigms focused on Oceania.

Although investigations like these of common features in Native epistemologies can be useful, there are multiple reasons to resist searching for 
a single Oceanic epistemology. Because, as Meyer emphasized, experience itself is shaped by culture, the different cultures of Oceania should be expected to produce different experiences of the "same" phenomenon, as well as different rules for making knowledge out of these experiences. Meyer concluded, "Because of this, the universalizing of Hawaiian epistemology is not possible" (200I, I $47 \mathrm{n}_{3}$ ); the universalizing of any other particular Oceanic epistemology or of a regional epistemology seems impossible, too.

Remaining for a cultural studies for Oceania, then, are the dual tasks of learning much more about the many particular valid epistemologies in the region and of developing ways for integrating these epistemologies into community-based research. Smith's 1999 review of multiple Kaupapa Māori projects undertaken in Aotearoa over the last two decades provides a fulsome discussion of some currently available research projects based on Oceanic epistemologies. Many more such discussions and examples of uses of Native epistemologies will likely appear in the years ahead.

\section{Transformed, Multiplied, and Transmixed Genres}

Some pioneers in a cultural studies for Oceania have self-consciously defied disciplinary expectations since the beginning of their careers. In his much-admired 1976 manifesto, Wendt mixed prose with poetry and rational analysis with extended metaphor. Greg Dening intertwined personal with objective voices in his influential histories (I980, I996). Hau'ofa has published anthropological studies and fiction (eg, I994), and acted as an instigator and muse to a variety of creative artists. Rob Wilson writes poetic cultural theory and theoretical poetry (see, eg, 2000). Thaman, author of some of the region's best-known contemporary poems (eg, I987), also composes articles aimed at inciting radical educational reform (eg, 2000, 2003). Subramani has in the last decade added community speeches (I995) and an aesthetic manifesto (200I) to his well-regarded accomplishments as a fiction writer and literary critic. Haunani-Kay Trask has published lyric poetry (I994, 2002) and political analysis (1999) while she was serving as director of the University of Hawai'i Center for Hawaiian Studies and as she continues to be an indigenous rights activist.

Many in a next generation of researchers who have been influenced by these just-mentioned pioneers are continuing the tradition of producing work that challenges disciplinary conventions of representation. Influential work in innovative genres appears regularly, for example, from those 
associated with the UsP Oceania Centre for Arts and Culture established by Hau'ofa. Elsewhere, first in Santa Cruz, then in Guam, and now in Ann Arbor, Diaz has produced both cultural criticism and a documentary film, Sacred Vessels (1997). In Santa Cruz, Suva, and now in Wellington, Teaiwa combines analysis, autobiography, and poetry in cultural productions that resist categorization in any single genre. Recently, in a compact disc made with Sia Figiel (Teaiwa and Figiel 2000), and in "L(o)osing the Edge," a two-columned analytical-historical exploration published in this journal (200Ib), Teaiwa further extended the scope of her challenges to what should count as "research reporting" in Oceania.

While Teaiwa transforms traditional literary genres to forge new ones, Hereniko offers work in multiple genres to demonstrate the inadequacy of the representations found in any single one. Hereniko's Woven Gods is a much-praised ethnography and history of clowning in his native Rotuma, accompanied with comparative references to clowning elsewhere (I995). Hereniko produced a documentary to accompany his book as well as subsequently influential essays on cultural identity and on the role of indigenous scholars in the region. Woven Gods and these articles alone would make Hereniko an influential figure among researchers in Oceania, but his reach extends even further. Hereniko's plays have been produced at multiple locations throughout the Pacific. His editorial work, both as coeditor (with Rob Wilson) of Inside Out: Literature, Cultural Politics, and Identity in the New Pacific (I999), and as the first general editor of the University of Hawai'i's Talanoa: Contemporary Pacific Literature series, have helped shape current understanding of contemporary Pacific literature. Hereniko has also convened influential conferences, written two children's books (I991, I997), and, most recently, turned to fictional filmmaking. Acting as coproducer, writer, and director, Hereniko followed a short, Just Dancing (1998), with The Land Has Eyes (forthcoming), a feature film shot entirely on location in Rotuma with indigenous actors and a largely indigenous crew.

Strategies of transforming genres and of producing work in multiple genres are associated much more closely with indigenous Pacific Islanders than with settlers and non-Natives. ${ }^{16}$ The choice of innovative strategies likely result, as White and Tengan speculated, from the fact that "there are few indigenous scholars for whom disciplinary training, institutional location, research interests, and methods converge to produce an easy identification of disciplinary identity" (2000, 40I) Those who feel uncomfortable within the confines of a discipline are less likely to limit their 
compositions to prescribed disciplinary forms. Should more indigenous Pacific Islanders become more "comfortable" within continental disciplines, however, we may see decreasing innovation, transmixing, and subversions of conventional academic research reporting.

Yet one hopes not, as less innovation could undermine much of the potency of the emerging cultural studies for Oceania. Reporting methods usually associated with continental disciplines poorly reflect the complexity of most indigenous experiences. It is likely within transmixed, transformed, and multiplied genres where displays of these (as yet) mostly ignored semantic spaces can best be created. The emerging cultural studies in Oceania should commit itself to constructing products that look different from those created by the disciplines that have traditionally investigated Oceania. If not, cultural studies will probably resemble most other Euro-American disciplines, working in Oceania but not being of or for it.

\section{ORALITY}

If these transmixed genres do not include a special emphasis on orality, the emerging cultural studies for Oceania will remain primarily a reading and writing activity cut off from the majority of people in the region. Well over half of the people of Oceania live in rural villages (White and Tengan 2000, 386). Though many are literate, most nonetheless are unlikely to accept attempts to reduce their experiences or interests to representations in written texts.

Suspicion of writing in Oceania extends far beyond villages. As Kame'eleihiwa wrote of Hawaiians, "We have evolved from a complex oral society and mistrust the power that the written words seems to wield" (1992, 380 25). It is not only that writing has been intimately associated with colonialist legal and penal systems, though this is a major source of mistrust, as Osorio explained (200I). An emphasis on writing has also been systematically used in schools throughout the region to teach Pacific Islanders that they are inadequate, even when they excel "at singing, dancing, composing, telling stories, and so on" (Hereniko 2000a, 84; see also Hezel I988; Meyer 200I; Thaman 2000a).

Orality contains “'Oceania's library' (the knowledge its people possess)" (Subramani 200I, I 5I). Much of this library is found in performance, in "dance, drama, public rituals, and ceremonies" (Hereniko 2000a, 88)-forms that researchers generally ignore or de-emphasize 
because they are more comfortable offering interpretations of written texts than of evanescent performances that "communicate multiple messages about a culture simultaneously" (Hereniko 2000a, 88-89). Relying mostly on writing, Francis X Hezel remarked, means relying mostly on a "stacked deck" that preordains what representations will be dealt (1988, 103).

An emphasis on orality and a corresponding de-emphasis on writing will encourage the emerging cultural studies for Oceania to open itself to the many hundreds of languages in the region that have but a tenuous and recent connection to their alphabetized forms. These languages, as Subramani put it, "carry the memory of the region" (200I, I 5 I) and so must constitute a center of any cultural studies aiming to serve Oceania. Hau'ofa warned that without a familiarity and commitment to these predominantly oral languages, researchers will miss the "grassroots resistance and other unnoticed but important events" of ordinary people in the region (2000, $45^{8)} \cdot .^{17}$

Spoken memories should not be associated with inaccuracy or held up to invidious comparisons with supposedly more reliable written accounts. Oral traditions are not "free-floating tales disconnected from the physical world, impossible of verification" (Hau'ofa 2000, 457). In fact, Borofsky has noted, the standards for judging oral texts in Oceania's oral cultures and written texts in Euro-American scholarly cultures overlap in significant ways. One especially prominent commonality is the reliance in both oral and written cultures on discussions of "how contexts shape content"; and in both oral and written cultures, accuracy emerges from "a process of negotiation involving conversations across divergent perspectives, with challenges and counterchallenges" (Borofsky 2000, IO, I I). By emphasizing orality, then, a cultural studies for Oceania will not repudiate an interest in reliability and validity. Rather, researchers will open themselves up to a wider range of sources than do current researchers who privilege written texts. ${ }^{18}$

Emphasizing orality does require substantial changes in researchers' working processes and in the forms they use in sharing results. Several of these changes were discussed earlier. In addition, the emphasis on orality encourages researchers to embrace a different perspective on truth. Hereniko has noted that while writing "encourages the view that there is but one truth" (2000a, 84-85), orality encourages a sense that multiple truths and perspectives exist simultaneously. The search for one truth may be connected as much with Euro-American monotheisms as with writing, because the " "one God' of Euro-Americans is associated with one story, 
with one text, and one very momentous earthly appearance" (Wood I999a, I36). Whatever its origins, an understanding that truth cannot be fixed in written texts is likely to form a foundational guideline for the emerging cultural studies for Oceania.

\section{THEORY}

The view that truth is multiple and perspectival brings us to theory, a final area where a consensus seems to be emerging among many practitioners of a cultural studies for Oceania. In part because "Indigenous peoples have been, in many ways, oppressed by theory" (Smith I999, 38), cultural studies in Oceania seeks alternatives to many of the theories, concepts and visions forged on continents. Gegeo spoke a common sentiment in declaring, "We need once and for all to eliminate the Anglo-Europeans categories that still tend to imprison us in outdated, meaningless terminologies that divide rather than unite us" (2001a, I79). Choosing between those theories that imprison and those that may empower is very difficult, however, for, as discussed earlier, Euro-American ideas such as national sovereignty, human rights, and articulation, among others, can be very helpful when deployed within decolonizing projects.

Over twenty-five years ago, Wendt explained the need for substituting Pacific for colonialist visions when he exhorted Pacific Islanders to supplant outsider experts and produce alternative "truths, insights, and intuitions into and interpretations of our cultures" (I976, 54). Wendt's project did not immediately receive the effort he recommended but exemplary theoretical breakthroughs have been made in Hau'ofa's series of essays (I993, I997, 2000).

Hau'ofa contrasted his indigenous perspective on the region with the dominant continental view. While Islanders traditionally understand themselves as living amid numerous watery pathways to adventure, trade, enemies, and friends, the invading Euro-Americans generally described Islanders as victims stuck on isolated and impoverished scraps of land. Colonizers introduced the separate borders of Melanesia, Micronesia, and Polynesia mentioned above; they created many additional conceptual barriers as well, Hau'ofa remarked, by drawing "imaginary lines across the sea, marking the colonial boundaries that, for the first time, confined ocean people to tiny spaces" $(1993,7)$. To replace the continental view of the Pacific as "islands in a far sea," Hau'ofa famously offered a vision of a "sea of islands." While the continental view "emphasizes dry surfaces in 
a vast ocean far from the centres of power," an Oceanic view is "more holistic" and views people and places "in the totality of their relationships" (Hau'ofa I993, 7).

In a later theoretical essay (2000), Hau'ofa offered a sketch of an Oceania historiography. Euro-American historians' emphasis on chronology is inappropriate for Oceania, he explained, as so much attention to when overlooks the "where, how, and in what sequence" that should instead be the focus of histories in the region $(2000,46 \mathrm{I})$. Precise dating is irrelevant, for in Oceania, "The past ... is going ahead of us, leading into the future, which is behind us" (2000, 460; see also Kame'eleihiwa I993, 22-23). Oceania's past, looming ahead, may be perceived in the present, as may ancestors, who exist also in the past and future. The past that is the focus of Native Oceanic histories literally rises ahead, "before," in the landscapes and seascapes of the region, which "are maps of movements, pauses, and more movements" (Hau'ofa 2000, 466). Landscapes and seascapes speak their multiple histories to those who know how to listen. "For the reconstruction and analysis of historical processes of this kind," Hau'ofa concluded, "we could use the notion of the spiral, which connotes both cyclic and lineal movements" (2000, 462).

Hau'ofa's and other Oceania-derived perspectives generally reflect the experiences of the majority of people in the region better than categories and ideas constructed elsewhere. Because the region is as rich in stories as it is in cultures, storytelling is one especially rich site for displaying Native perspectives. As Osorio has said of Hawaiian mo'olelo, many of these stories function "to explain our lives" (200I, 360). Mo'olelo, and related stories by other names told throughout Oceania, explicate behavior for people in Oceania in ways analogous to how tales of structures, conjunctures, articulations, and related concepts explain behavior for readers of anthropology, political science, psychology, sociology, and similar Euro-American texts. Oceania's stories can thus be seen as a Native form of theory, though Oceania's stories often go beyond description and analysis to offer explicit suggestions as well on how best to live. ${ }^{19}$

Theory and storytelling in continental traditions aim for "best" or "accurate" or "true" versions, as Euro-American researchers generally embrace the enlightenment tradition that associates knowledge with static formulations like those found in mathematics and physics. Oceanic theory and storytelling, on the other hand, should be expected to vary according to the occasions of their utterance. The best critical analysis of a story in Oceania often takes the form of a retelling in a new version of 
that same story, altered to include different emphases, events, or personal references. The new cultural studies for Oceania will likely recognize variant performances of the "same" story or theory as a valued form of analysis.

In adopting stories as a form of theorizing and analysis, a cultural studies for Oceania should open itself up as well to the particular power of personal stories. As Hereniko has observed, analysis that ignores "the emotional landscape of those responsible" for events ignores the very core of those events (2000a, 85; see also Hereniko 200ob). Teaiwa's work provides especially rich demonstrations of the power of theorizing in and with the personal (I995b, I997, 200Ib).

The emerging cultural studies for Oceania accepts that few locally inflected theories are likely to be equally applicable across such a large and diverse region. What Silva's I999 analysis shows to have been true of the dual meaning of petition gathering among Hawaiians in the I890s, for example, may not apply generally to petition gatherings that took place about the same or at other times elsewhere in the Pacific. Indeed, constructing multiple concepts, visions, and perspectives is likely to be a core task of a locally inflected cultural studies for Oceania. David Hanlon concluded that contemporary Pacific histories properly take forms "sung, danced, chanted, spoken, carved, woven, painted, filmed, sculpted, and rapped, as well as written" (2003, 30; see also Hezel 1998). Theorizing in Oceania should take place in equally diverse forms. While westerners generally accept the Aristotelian distinction between rhetorical and poetic texts, no such dichotomy of fact and fiction, of persuasion and entertainment, should limit a cultural studies for Oceania as it evolves its regionserving perspectives (Wood I999b).

Hau'ofa has cautioned that "if we fail to construct our own realities other people will do it for us" (2000, 453). Theory building in a cultural studies for Oceania must continually emphasize the plurality contained in Hau'ofa's reference to "realities." Embracing any single alternative, even it if it is rooted in Oceania's precolonial traditions, Gegeo warned, "simply replaces one hegemony with another and repeats our colonial experience" (200Ia, I 82). Any new hegemony would generate a new homogenization when what seems most needed in the region now is a recognition that Oceania should in the future, as it did in the past, sustain "a cultural diversity more varied than any other in the world" (Wendt I976, 57). According to Gegeo, researchers in the region need a "multiplicity of 
Pacific voices" (200Ia, I 82). A cultural studies for Oceania needs, as well, a multiplicity of Pacific visions, categories, metaphors, and theories, with no single one dominating the others.

\section{Conclusion}

As practitioners of the emerging cultural studies for Oceania develop these various new research practices and theories, they will often focus on topics specific to the region, topics different from those associated with continental disciplines. Still, even when familiar continental research topics remain the focus, work in the emerging cultural studies will take new forms as it embraces local and regional identities, emphasizes processes, requires reciprocities, revives and reinvents traditional epistemologies, utilizes distinct genres of representation, values the region's oral legacies, and relies on diverse Native concepts, theories, and perspectives.

Specific circumstances, locations, and practitioner abilities will dictate which practices are emphasized in particular projects. The region's diverse, emerging practices are likely to cross-pollinate, forming hybrid practices unlike any seen before. The precise forms the emerging cultural studies will take thus cannot, and need not, be specified. What can be predicted, though, is that fierce obstacles will continue to oppose the establishment of a cultural studies that is in, of, and for the interests of the majority in Oceania. On various continents, hegemonic forces encouraging further globalization have already co-opted much of what passes as cultural studies research. Most cultural studies is now simply conventional "scholarship" masquerading under a new, trendier name. Such cultural studies work might better be called "anthropology," "media studies," "history," "cultural criticism," "theory," or other comparable Eurocentric names. ${ }^{20}$

Institutional pressures are encouraging the emerging cultural studies in Oceania to follow the well-worn colonialist paths of earlier research in the region. For some in Oceania, cultural studies is metamorphosing into just one more specialized discourse, practiced by scholars for scholars, uttered obscurely at elite conferences, published in texts only professionals comprehend. The institutional rewards for those who do such conventional research will continue to far exceed the support given any who embrace different, community-based, cooperative forms of knowledge production. Still, while these many obstacles make a radical cultural studies for Oceania difficult to create and sustain, they do not make it impossible. Many 
people are striving to build an alternative. In a decade or so it should be evident whether cultural studies practitioners in Oceania have managed to overcome the many obstacles to develop a set of practices that enhances the region's uniqueness.

Thanks to Reshela DuPuis, Phyllis Frus, Jan Rensel, Noenoe K Silva, Geoff White, Naomi Wood, and anonymous referees of this journal for encouragement and suggestions.

\section{Notes}

I Separate, well-known explorations of the concept of "Oceania" by Albert Wendt (1976) and Epeli Hau'ofa (1993; 1997) explain why this term seems preferable to "Pacific," "Pacific Islander," and other alternatives.

Vicente M Diaz's dissertation, "Repositioning the Missionary," completed at the University of California, Santa Cruz (UCSC) in I992, was probably the first extended attempt to bring a cultural studies perspective to bear on an Oceanic topic. See also Diaz 1994. The development of a concentration in Cultural Studies in Asia/Pacific in the English Department of the University of Hawai'i at Mānoa (UHM), led by Rob Wilson (who later moved to UCSC), was among the first attempts to institutionalize a continental cultural studies perspective in Oceania (see <http://maven.english.hawaii.edu/grad/cultstud.html>). The UHM and East-West Center's graduate certificate program in International Cultural Studies, created by Geoff White and Ming-Bao Yue, followed soon after (see $<$ http://www2.hawaii.edu/ culture/>). Keith Camacho's valuable "Native Cultural Studies in the Pacific Islands" was one fruit of this program (2000). The pioneering ucsc conference, "Native Pacific Cultural Studies on the Edge" (held in February 2000), and the theoretical grounding for that conference and for the special issue of The Contemporary Pacific coauthored by Diaz and J Kēhaulani Kauanui (200I), have further solidified the importance of cultural studies in Oceania. (Diaz and Kauanui emphasized diasporic Natives more than does the cultural studies for Oceania described in this essay.) Also important in bringing cultural studies to Oceania is Teresia K Teaiwa's ambitious dissertation, "Militarism, Tourism and the Native: Articulations in Oceania" (200I), which relies on the cultural studies concept of "articulations" to develop new ways of theorizing the region.

2 I have adopted the phrase "sea of knowledges" after hearing Edvard Hviding use it in answering a question from Epeli Hau'ofa at the conference, "Pacific 
Studies 2000: Honoring the Past, Creating the Future," convened by the UHM Center for Pacific Islands Studies in Honolulu in November 2000. (The spring 2003 issue of this journal [The Contemporary Pacific I 5 (I)] is a special issue arising from that conference.)

3 See, for example, the work of Gegeo (1994, 1998; Gegeo and Watson-Gegeo 200I), Vilsoni Hereniko (2000a), and Manulani Aluli Meyer (1998; 200I). Issues of epistemology are further discussed later in this article.

4 See my discussion of how non-Native rhetoric has been used in Hawai'i to call attention to an older, Native rhetoric, and of general problems associated with the translation of oral texts (Wood I999a, I 5-I 7, 55-57).

5 Gegeo has also argued for distinguishing between those who are indigenous and those who are Native. He pointed out, "Native' is an insult that Melanesians occasionally hurl at one another in anger. Increasingly, Melanesians prefer 'Indigenous' in political and scholarly discussions when referring to people's connections to place" (200Ib, 505). But for simplicity here, I will use Native to refer to indigenous people of Oceania, employing a capital letter to support what Lilikalā Kame'eleihiwa calls the "incipient sovereignty" that can be asserted through "selective capitalization" (1992, 342).

6 In the context of the British Commonwealth and its attendant diaspora, Hall pioneered a view of identities as subject to continual transformations according to the "'play' of history, culture and power" (I990, 225; see also Hall I996). Paul Gilroy described this as the view that identity formation "is a chaotic process that can have no end" (1996, 238). Gegeo made a similar suggestion for Pacific Islander identities when he maintained that these identities are "portable" (200Ib, 50I).

7 Barbara Burns McGrath described how some Samoans in Seattle articulate multiple community memberships to construct unique diasporic but nonetheless self-consciously Native Samoan identities (2002). See also Pacific Diaspora: Island Peoples in the United States and Across the Pacific (Spickard, Rondilla, and Wright 2002).

8 Gegeo, for example, discussed the complicated but not atypical situation of Malaitans who lived for generations on Guadalcanal but were then driven "back to their heritage island of Malaita" (200Ib, 497). The resulting overcrowding on Malaita is creating immense pressures for mass emigration. Still, according to Gegeo, Malaitan epistemologies will likely keep Malaitans considering themselves a single people, regardless of where most may live. See also Gegeo and Watson-Gegeo 200I; Teaiwa I994.

9 Proponents of various academic disciplines, especially anthropology (eg, Asad 1995; Hymes 1999; Harrison 199I), have fretted over their sometimes conflicting obligations to construct Eurocentric knowledge while, at a minimum, "doing no harm" to the people studied. Still, though no Euro-American discipline 
as yet bases its very theories, categories, and methods on the knowledge and needs of those it studies, this is what a cultural studies of and for Oceania aims to do.

Io The extended studies by Osorio (2002) and Noenoe K Silva (IP b) continue the resurgence of the writing of Hawaiian history by Natives that was inaugurated by Kame'eleihiwa's pioneering book.

I I Kame'eleihiwa argued that while there "is a great lack of pono in Hawai' $i$ " today, pono remains the central goal of Hawaiians (1992, 316). She wrote, "Perhaps there can be no pono in the Hawaiian universe so long as Hawaiians expect to live in harmony with foreigners ... Certainly there can be no pono in Hawai'i until we Hawaiians regain control of our ancestor's 'Āina" (I992, 3I 8). She also noted: "Kalākaua had discovered that it was impossible to rule Hawai'i with pono for both Natives and foreigners-their worlds were too different" (3 I 5 ).

Osorio (2002) and Sally Engle Merry (2000) offered related, independent interpretations of the role of law making in disempowering nineteenth-century Hawaiians. Silva examined how Hawaiians in the I 890 os worked simultaneously in the external political and internal spiritual spheres to oppose the annexation of the Republic of Hawai'i (I999, IP a).

I2 In her examination of the videos of two Kanaka Maoli women (in "Kapa Aloha: Personal Journey, Cultural Survival," the penultimate chapter of her 1997 dissertation), DuPuis offered a vivid example of the gains and costs of committing to process over product. DuPuis stressed that, in narrating the conception, production, and mostly private distribution of their single work, the video Kapa Aloha, Kawaikaula'au Aona-Ueoka and Nālani Mattox believed that their completed video would be of little value if people were colonized, exploited, disrespected, or otherwise abused during production. Because these producers also maintained only some contexts were proper for viewing the video, they never released Kapa Aloha to the public.

I3 Kame'eleihiwa similarly argued that Native order was based on reciprocity, on "reciprocal obligation" (I992, I0). Also, Trask maintained, "As in all of Polynesia, so in Hawai'i: younger sibling must care for and honor elder sibling who, in return, will protect and provide for younger sibling. Thus Hawaiians must nourish the land, our ancestor. This relationship is more than reciprocal. It is familial" (I993).

I4 For a different example of including the community in creating and guiding research, see McGrath's study of Samoans in Seattle (2002).

I 5 After reviewing the difficulties of reconciling what he calls "Outlander" and "Islander" perspectives, Borofsky suggested Binney's Redemption Songs (I997) and Salmond's Two Worlds (I99I) as models that "provide subtle, multifaceted analyses" that have been "enthusiastically" accepted by both Islanders and Outlanders (Borofsky 2000, 22-27).

I 6 Among non-Natives and settlers, only Greg Dening, Subramani, and Rob Wilson have created remotely comparable compositions. 
I7 Donald Denoon and Roderic Lacey's edited Oral Tradition in Melanesia contains many useful chapters examining issues of orality and modernity (I98I). For more about the importance of indigenous languages to an understanding of Oceania, see Smith I999 and Silva I999, IP a, and IP b.

I8 A "wider range of sources" is just what Borofsky says Pukapukans use when compared with professional Pacific historians $(2000,9)$. See also Borofsky's detailed examination of Pukapukan epistemology (I987).

I9 Silva pointed to this, written by Kaukaliu in the Hawaiian-language newspaper Ka Hoku o ka Pakipika in I86I:

O ka mooolelo ua like ia me he aniani la e hoike mai ana i ka hana a ke kanaka i hana'i mamuli o kekahi kumu. . . . Ua hoike mai ka mooolelo i ka hope oia mau hana, ina he maikai, a ino paha, i loaa mai i ke kanaka ... e hana ana ia mau mea.

Mo'olelo is like a mirror showing the action a person takes for a certain reason.... The mo'olelo shows the results of these actions, if they were good or bad, [and their effects] upon the person doing those things. (Translation in Silva IP a).

20 Unfortunately, Hall's laments over a decade ago about the professionalization and textualization of cultural studies little slowed these trends (1992). Angela McRobbie's related critique of the depoliticization of cultural studies also had little impact (1992). See also, however, Jon Stratton and Ien Ang's warnings about viewing the engaged practices of an earlier British cultural studies as the "true" or "pure" version of the field (1996).

\section{References}

Asad, Talal, editor

I995 Anthropology and the Colonial Encounter. New York: Humanity Books. Original edition, London: Ithaca Press, and Atlantic Highlands, NJ: Humanities Press, 1973.

Binney, Judith

1997 Redemption Songs: A Life of the Nineteenth-Century Maori Leader Te Kooti Arikirangi Te Turuki. Honolulu: University of Hawai'i Press. Original edition, Auckland: Auckland University Press, I995.

Borofsky, Rob

I987 Making History: Pukapukan and Anthropological Constructions of Knowledge. New York: Cambridge University Press.

2000 An Invitation. In Remembrance of Pacific Pasts: An Invitation to Remake History, edited by Rob Borofsky, I-30. Honolulu: University of Hawai'i Press. 
Camacho, Keith

2000 Native Cultural Studies in the Pacific Islands. International Cultural Studies Capstone presentation. East-West Center, Honolulu, 8 December.

Chakrabarty, Dipesh

2000 Provincializing Europe: Postcolonial Thought and Historical Difference. Princeton: Princeton University Press.

Clifford, James

1997 Routes: Travel and Transculturation in the Late Twentieth Century. Cambridge: Harvard University Press.

2000 Valuing the Pacific-An Interview with James Clifford. In Remembrance of Pacific Pasts, edited by Rob Borofsky, 92-99. Honolulu: University of Hawai'i Press.

Dening, Greg

I980 Islands and Beaches: Discourse on a Silent Land: Marquesas 1774I880. Honolulu: University of Hawai'i Press.

I996 Performances. Chicago: University of Chicago.

Denoon, Donald, and Roderic Lacey, editors

I98I Oral Tradition in Melanesia. Port Moresby: University of Papua New Guinea.

Diaz, Vicente $M$

I992 Repositioning the Missionary: The Beatification of Father Diego Luis de Sanvitores and Chamorro Culture History. PhD dissertation. University of California, Santa Cruz.

I994 Simply Chamorro: Telling Tales of Demise and Survival in Guam. The Contemporary Pacific 6:29-58.

1997 Sacred Vessels: Navigating Tradition and Identity in Micronesia. GMF, Guam: Moving Islands Production. Video.

Diaz, Vicente M, and J Kēhaulani Kauanui

200 I Native Pacific Cultural Studies on the Edge. The Contemporary Pacific I 3:31 5-342.

DuPuis, Reshela P

I997 Documenting Community: Activist Videography in Hawai'i. PhD dissertation. University of Michigan.

Fortune, Kate

2000 The Pacific Way. In The Pacific Islands, An Encyclopedia, edited by Brij V Lal and Kate Fortune, 486-487. Honolulu: University of Hawai'i Press.

Gegeo, David Welchman

I994 Kastom and Bisnis: Toward Integrating Cultural Knowledge into Rural Development in the Solomon Islands. PhD dissertation. University of Hawai'i. 
I998 Indigenous Knowledge and Empowerment: Rural Development Examined from Within. The Contemporary Pacific Io:289-3I 5.

200Ia (Re)visioning Knowledge Transformations in the Pacific: A Response to Subramani's "The Oceanic Imaginary." The Contemporary Pacific I $3: 178-183$.

200Ib Cultural Rupture and Indigeneity: The Challenge of (Re)Visioning "Place" in the Pacific. The Contemporary Pacific I3:49I-507.

Gegeo, David Welchman, and Karen Ann Watson-Gegeo

$200 \mathrm{I}$ "How We Know": Kwara'ae Rural Villagers Doing Indigenous Epistemology. The Contemporary Pacific I 3:55-88.

2002 Whose Knowledge? Epistemological Collisions in Solomon Islands Gilroy, Paul Community Development. The Contemporary Pacific I4:377-4I I.

I99I There Ain't No Black in the Union Jack: The Cultural Politics of Race and Nation. Chicago: University of Chicago Press.

I993 The Black Atlantic: Modernity and Double Consciousness. New York: Verso.

I996 British Cultural Studies and the Pitfalls of Identity. In Black British Cultural Studies: A Reader, edited by Houston A Baker, Jr, Manthia Diawara, and Ruth A Lindeborg, 223-239. Chicago: University of Chicago Press.

Grace, Patricia

I998 Cousins. Talanoa Series. Honolulu: University of Hawai'i Press. Hall, Stuart

I990 Cultural Identity and Diaspora. In Identity: Community, Culture, Difference, edited by Jonathan Rutherford, 222-237. New York: New York University Press.

I992 Cultural Studies and its Theoretical Legacies. In Cultural Studies, edited by Lawrence Grossberg, Cary Nelson, and Paula A Treicher, 277-294. New York: Routledge.

I996 Introduction: Who Needs "Identity"? In Questions of Cultural Identity, edited by Stuart Hall and Paul du Gay, I-I7. Thousand Oaks, CA: Sage.

Hanlon, David

2003 Beyond "the English Method of Tattooing": Decentering the Practice of History in Oceania. The Contemporary Pacific I 5: 19-40.

Harrison, Faye V, editor

I99I Decolonizing Anthropology: Moving Further Toward an Anthropology for Liberation. New York: American Anthropological Association.

Hau'ofa, Epeli

I993 Our Sea of Islands. In A New Oceania: Rediscovering Our Sea of 
Islands, edited by Eric Waddell, Vijay Naidu, and Epeli Hau'ofa, 2-I6. Suva: School of Social and Economic Development, University of South Pacific. Reprinted in The Contemporary Pacific 6: I47-I6I (1994), and in Inside Out, edited by Vilsoni Hereniko and Rob Wilson, 27-38. Lanham, MD: Rowman and Littlefield (I999).

I994 Tales of the Tikongs. Talanoa Series. Honolulu: University of Hawai $i$ Press. Original edition, Auckland: Longman Paul, 1983.

1997 The Ocean in Us. Dreadlocks in Oceania I:I 24-I48. Reprinted in The Contemporary Pacific IO:39I-4IO (I998).

2000 Epilogue: Pasts to Remember. In Remembrance of Pacific Pasts: An Invitation to Remake History, edited by Robert Borofsky, 453-47I. Honolulu: University of Hawai'i Press.

Hereniko, Vilsoni

I99I The Wicked Cat. Suva: Institute of Education, University of the South Pacific.

I995 Woven Gods: Female Clowns and Power in Rotuma. Pacific Islands Monograph Series I 2. Honolulu: Center for Pacific Islands Studies and University of Hawai'i Press.

I997 Sina and Tinilau. Suva: Institute of Pacific Studies, University of the South Pacific, in association with the Fiji Writers' Association.

1999 Representations of Cultural Identities. In Inside Out, edited by Vilsoni Hereniko and Rob Wilson, I37-I66. Lanham, MD: Rowman and Littlefield. Originally published in Tides of History: The Pacific Islands in the Twentieth Century, edited by K R Howe, Robert C Kiste, and Brij V Lal , 406-434. Honolulu: University of Hawai'i Press, 1994.

2000a Indigenous Knowledge and Academic Imperialism. In Remembrance of Pacific Pasts, edited by Robert Borofsky, 78-9г. Honolulu: University of Hawai'i Press.

2003 Interdisciplinary Approaches in Pacific Studies: Understanding the Fiji Coup of I9 May 2000. The Contemporary Pacific I 5:75-90.

Hereniko, Vilsoni, and Jeannette Paulson

1998 Just Dancing. Honolulu: Te Maka Productions. Video.

Forthcoming The Land Has Eyes. Honolulu: Te Maka Productions. Motion picture.

Hereniko, Vilsoni, and Rob Wilson, editors

1999 Inside Out: Literature, Cultural Politics, and Identity in the New Pacific. Lanham, MD: Rowman and Littlefield.

Hezel, Francis X

I988 New Directions in Pacific History: A Practitioner's Critical View. Pacific Studies I I (3): IOI-I IO.

Hymes, Dell H, editor

1999 Reinventing Anthropology. Ann Arbor: University of Michigan Press. Original edition, New York: Pantheon Books, 1972. 
Jolly, Margaret

200 I On the Edge? Deserts, Oceans, Islands. The Contemporary Pacific I 3 : 4I 7-466.

Kame'eleihiwa, Lilikalā

I992 Native Land and Foreign Desires: Pehea Là E Pono Ai? Honolulu: Bishop Museum Press.

Katz, Richard

I993 A Straight Path: A Story of Healing and Transformation in Fiji. Reading: Addison-Wesley.

Kempf, Wolfgang

I999 Cosmologies, Cities, and Cultural Constructions of Space: Oceanic Enlargements of the World. Pacific Studies 22 (2): 97-I I 4.

McGrath, Barbara Burns

2002 Seattle Fa'a Sämoa. The Contemporary Pacific I4:307-340.

McRobbie, Angela

I992 Post-Marxism and Cultural Studies: A Post-script. In Cultural Studies, edited by Lawrence Grossberg, Cary Nelson, and Paula A Treicher, 719-730. New York: Routledge.

Merry, Sally Engle

2000 Colonizing Hawai $i$ : The Cultural Power of Law. Princeton: Princeton University Press.

Meyer, Manulani Aluli

I998 Native Hawaiian Epistemology: Contemporary Narratives. DEd dissertation. Harvard University.

200I Our Own Liberation: Reflections on Hawaiian Epistemology. The Contemporary Pacific I $3: \mathrm{I} 24-\mathrm{I} 48$.

Narokobi, Bernard

I980 The Melanesian Way. Boroko: Institute of Papua New Guinea Studies.

Osorio, Jonathan Kamakawiwo'ole

200 I "What Kine Hawaiian Are You?” A Mo'olelo about Nationhood, Race, History and the Contemporary Sovereignty Movement in Hawai'i. The Contemporary Pacific I 3:343-358.

2002 Dismembering Lähui: A History of the Hawaiian Nation to I887. Honolulu: University of Hawai'i Press.

Owen, Chris

I990 Man Without Pigs. Watertown: Documentary Educational Resources. Video.

Pukui, Mary Kawena, E W Haertig, and Catherine A Lee

1972, I979 Nānā I Ke Kumu (Look to the Source). 2 volumes. Honolulu: Queen Lili'uokalani Children's Center.

Salmond, Anne

I995 Maori Epistemologies. In Reason and Morality, edited by Joanna Overing, 240-263. New York: Tavistock. 
I99I Two Worlds: First Meetings between Maori and Europeans I642I772. Honolulu: University of Hawai'i Press.

Silva, Noenoe K

I999 Ke Kū‘e Kūpa‘a Loa Nei Mākou: Kanaka Maoli Resistance to Colonization. PhD dissertation. University of Hawai'i.

IP a Dancing on the Page: Representations of Hula in Hawaiian Literature During the Legal Ban (I86I). In Law and Empire in the Pacific, edited by Don Brenneis and Sally Engle Merry. Santa Fe, NM: School for American Research.

IP b Aloha 'Āina: Native Hawaiian Resistance and Persistence. Durham, NC: Duke University Press.

Smith, Linda Tuhiwai

I999 Decolonizing Methodologies: Research and Indigenous People. New York: Zed Books.

Spickard, Paul, Joanne Rondilla, and Debbie Hippolite Wright, editors

2002 Pacific Diaspora: Island Peoples in the United States and Across the Pacific. Honolulu: University of Hawai'i Press.

Stratton, Jon, and Ien Ang

I996 On the Impossibility of a Global Culture Studies: 'British' Cultural Studies in an "International Frame." In Critical Dialogues in Cultural Studies, edited by David Morley and Kuan-Hsing Chen, 36I-39I. New York: Routledge.

Subramani

I995 Altering Imagination. Suva: Fiji Writers' Association.

200I The Oceanic Imaginary. The Contemporary Pacific I3:149-162.

Teaiwa, Teresia K

I994 bikinis and other s/pacific n/oceans. The Contemporary Pacific 6:87I IO.

I995b Scholarship from a Lazy Native. In Work in Flux, edited by Emma Greenwood, Andrew Sartori, and Klaus Neumann, 58-72. Melbourne: History Department, University of Melbourne.

I997 Yaqona/Yagona: Roots and Routes of a Displaced Native. Dreadlocks I:7-I3.

I999 Reading Paul Gauguin's Noa Noa with Epeli Hau'ofa's Kisses in the Nederends: Militourism, Feminism, and the "Polynesian" Body. In Inside Out, edited by Vilsoni Hereniko and Rob Wilson, 249-263. Lanham, MD: Rowman and Littlefield.

200Ia Militarism, Tourism and the Native: Articulations in Oceania. PhD dissertation. University of California, Santa Cruz.

200Ib Lo(o)sing the Edge. The Contemporary Pacific I 3:343-358. 
Teaiwa, Teresia K, and Sia Figiel

2000 Terenesia. Honolulu: Hawai'i Dub Machine and Elepaio Press. Compact disc.

Thaman, Konai Helu

1987 Hingano: Selected Poems, I966-1986. Suva: Mana Publications.

2000 Of Daffodils and Heilala: Understanding (Cultural) Context in Pacific Literature. In Re-placing America: Conversations and Contestations, edited by Ruth Hsu, Cynthia Franklin, and Suzanne Kosanke, 40-50. Honolulu: University of Hawai'i Press.

2003 Decolonizing Pacific Studies: Indigenous Perspectives, Knowledge, and Wisdom in Higher Education. The Contemporary Pacific I 5:I-I7.

Trask, Haunani-Kay

I993 Environmental Racism in the Pacific Basin. Conference on Environmental Racism. University of Colorado at Boulder. <http://www 2. hawaii.edu/shaps/hawaii/racism.html> Accessed 28 May 1997.

1994 Light in the Crevice Never Seen. Corvallis: Calyx.

1999 From a Native Daughter: Colonialism and Sovereignty in Hawai $i$. Revised edition. Honolulu: University of Hawai'i Press. Original edition, Monroe, ME: Common Courage Press, 1993.

2002 Night is a Sharkskin Drum. Honolulu: University of Hawai'i Press.

Waddell, Eric, Vijay Naidu, and Epeli Hau'ofa, editors

1993 A New Oceania: Rediscovering Our Sea of Islands. Suva: University of South Pacific.

Waiko, John Dademo

I982 Be Jijimo: A History According to the Tradition of the Binandere People of Papua New Guinea. PhD dissertation. Australian National University.

Wendt, Albert

I976 Toward a New Oceania. Mana I:49-69.

White, Geoffrey M, and Ty Kāwika Tengan

$200 \mathrm{I}$ Disappearing Worlds: Anthropology and Cultural Studies in Hawai'i and the Pacific. The Contemporary Pacific I3:38I-4I6.

Wilson, Rob

2000 Reimagining the American Pacific: From South Pacific to Bamboo Ridge and Beyond. Durham, NC: Duke University Press.

Wood, Houston

I999a Displacing Natives: The Rhetorical Production of Hawai'i. Lanham, MD: Rowman and Littlefield.

I999b Preparing to Retheorize the Texts of Oceania. In Inside Out, edited by Vilsoni Hereniko and Rob Wilson, 38I-398. Lanham, MD: Rowman and Littlefield. 


\section{Abstract}

A new research perspective is emerging in Oceania, one based on combining practices drawn from both Pacific Islander and continental cultures. This emerging perspective, here labeled "cultural studies for Oceania," differs from most Pacific Studies research as well as from continental cultural studies. This new practice is characterized by combinations of the following: an emphasis on personal identities and on specifying distinct research roles for Pacific Islanders and non-Natives; efforts to forge a unifying regional identity; research focused on processes more than on final products; reciprocity between researchers and those they study; prominent use of Oceania epistemologies; unconventional researchreporting genres; reliance on oral practices and traditions; dependence on Pacific Islander models, concepts, and theories. Research programs that embrace these features offer a promising alternative to the dominant research practices in the region, which continue to perpetuate earlier colonizations.

KEYWORDS: cultural studies, decolonization, epistemology, identity, Oceania, oral traditions, Pacific studies 